DOI 10.37882/2500-3682.2020.05.19

\title{
ЭКЗИСТЕНЦИАЛЬНАЯ ТЕРАПИЯ РОК-МУЗЫКИ (НА ПРИМЕРЕ «РУССКОГО» РОКА)
}

\section{EXISTENTIAL THERAPY OF ROCK MUSIC (ON THE EXAMPLE OF «RUSSIAN» ROCK) \\ E. Fetisova}

Summary:The article presents a philosophical analysis of the phenomenon of the therapeutic influence of rock music on a multimillion audience. An integrative approach to the analysis of this phenomenon is used, namely the combination of the traditions of existential philosophy and existential psychology. Existential therapy within the framework of existential psychology is aimed at realising a person's profound understanding of his existence in order to reveal his personal potential, understand his true place in life, accept his "I", be aware of responsibility for personal choice, find the meanings of his own life. In the article existential therapy is considered in the same way, only rock music, namely "Russian rock", acts as an existential therapist.

Keywords: existential analysis, existential therapy, the problem of freedom and responsibility, life and death, love and loneliness, the meaning of life, rock music.

\author{
Фетисова Евгения Николаевна \\ К.ф.н, дочент, ФГБОУВО «Тихоокеанский \\ государственный университет», г. Хабаровск \\ evseneya@mail.ru
}

Аннотация: В статье представлен философский анализ феномена терапевтического влияния рок-музыки на многомиллионную аудиторию. Используется интегративный подход к анализу данного феномена, а именно соединение традиций экзистенциальной философии и экзистенциальной психологии. Экзистенциальная терапия в рамках экзистенциальной психологии направлена на осознание человеком глубинного понимания своего существования с целью раскрытия личностного потенциала, понимания истинного места в жизни, принятие своего «я», осознания ответственности за личный выбор, нахождения смыслов собственной жизни. В статье экзистенциальная терапия рассматривается в таком же ключе, только в роли экзистенциального терапевта выступает рок-музыка, а именно «русский рок».

Ключевые слова: экзистенциальный анализ, экзистенциальная терапия, проблема свободы и ответственности, жизни и смерти, любви и одиночества, смысла жизни, рок-музыка.

Классический экзистенциальный анализ - это всегда диалог. Очень важно достучаться до субъективных ценностей клиента, его чувств, переживаний. Число разновидностей чувств и переживаний человека ограничено, но здесь акцент делается именно на их экзистенциальной стороне. Почему рок-музыка находит отклик в «Я»? Почему происходит диалог в виде сопереживания? Почему твоя экзистенция резонирует с текстом и музыкой, оформляется ритмом? Происходит терапевтический эффект, который и влечет к рок-музыке столько таких разных поклонников. Ситуация, когда ты переживаешь чтото очень личное, и вдруг в музыке мгновенно слышишь проговаривание твоей ситуации.

И так, экзистенциальная терапия в рамках экзистенциальной психологии направлена на осознание человеком глубинного понимания своего существования с целью раскрытия личностного потенциала во всех сферах жизни, правильного понимания своего истинного места в жизни, принятие своего «Я», осознания ответственности за личный выбор и поступки, нахождения смыслов собственной жизни.

В данной статье экзистенциальная терапия рассма- 
тривается в таком же ключе, только в роли экзистенциального терапевта выступает рок-музыка. А именно так называемый «русский рок», то есть рок-музыка с текстом песен на русском языке.

Из всего разнообразия русскоязычного рока для нашего анализа выберем несколько групп, которые имеют большую популярность, длительную творческую историю (не менее 15 лет), солидную армию поклонников. Остановимся на таких легендарных рок-коллективах как Сплин, Би-2, Lumen, Аквариум (включая сольное творчество БГ), Смысловые галлюцинации.

Экзистенциальная тревога проявляется перед лицом таких данностей бытия как жизнь и смерть, выбор и ответственность, свобода и необходимость, смысл существования и его бессмысленность, творчество и забвение, любовь и одиночество. Определим эти экзистенциальные данности в четыре группы, через которые и будем анализировать феномен экзистенциальной терапии российской рок-музыки:

1. проблема свободы, ответственности, выбора;

2. проблема жизни и смерти;

3. проблема любви и одиночества;

4. проблема смысла жизни.

\section{Проблема свободы, ответственности, выбора}

Основным, если можно так сказать, генетическим проявлением экзистенции является концепт «свобода». Человек здесь становится перед выбором из множества вероятностных возможностей. Какая будет наиболее счастливой? Какие механизмы необходимо задействовать, что бы избежать ошибки? Как быстро надо сделать выбор? Естественно, что на стадии выбора возникает тревога.

При условии Быть никогда не везло,

Остается забыть или помнить не Зло.

И от нечего ждать никогда не грустить,

Без ответа узнать, что пора уходить.

Что пора перестать продвигаться на слух,

Что не стоит искать совпадения двух.

Там, где может быть дом - и уже налегке

Я стою на дверном сквозняке.

(Би-2 «Унисон»)

Человек в течение жизни проходит множество таких переломных моментов, когда необходимо сделать выбор. От этого зависит, каким будет следующий этап его жизни. Осмысление выбора помогает человеку больше разобраться в себе, приблизиться к постижению своего «Я», взять ответственность на себя за свое решение.

Ты все придумал сам. Кого теперь винить?

Надеюсь, хватит дней хоть что-то изменить...

(Lumen «Один ответ»)
Тревога здесь естественна, особенно для молодого возраста, когда жизненные ориентиры еще не имеют четких очертаний. Рок-музыка уделяет проблеме свободы, ответственности, выбора большое внимание.

У насекомых, размазанных по стеклам фар

Нет выбора, а у тебя есть этот дар

Или проклятье, как хочешь назови

То, что кипит и дышит у тебя в груди.

(Lumen «Не простил»)

За Свободу можно второй раз родиться,

Сдохнуть тысячу раз, но не отступиться,

Бороться и драться, проиграть, но не сдаться,

Идти много лет, но все же добраться.

Я задыхаюсь, мне все теснее с каждым годом.

Я широко раскрыл глаза, но не могу найти свободу... (Lumen «Свобода»)

Здесь во многом отражены чаяния людей, которые все поставили на кон ради внутренней свободы. Необходимо собрать свою волю и через падения, ошибки, отчаяние все равно держать «глаза широко раскрытыми», чтобы увидеть путь к свободе.

Приветствую тебя, безумный мир.

Ты сделан из железа и свинца.

И я пойду с тобою до конца.

Возьми меня с собой, прекрасный мир.

(Смысловые галлюцинации «Волшебный мир»)

На этом пути можно проиграть, но не сдаться, то есть понять, что ты и есть тот, кто является определяющей причиной своих действий.

Я счастлив тем, как сложилось все,

Даже тем, что было не так.

Даже тем, что ветер в моей голове,

И в храме моем бардак.

(Аквариум «25 к 10»)

Как говорилось выше, цель экзистенциальной терапии - это помощь отдельно взятому человеку в осознании глубинного понимания своего существования. Следствием этого является раскрытие личностного потенциала. Этот путь сложен, тернист, он сопровождается и периодами слабости, неверия, желанием все бросить.

Я мог бы написать эпос, но к чему рисковать камуфляжем?

Мог бы взять холст и кисти, но это ничего не меняет.

(Аквариум «Танцы на грани весны»)

Разочарование в выборе дня вчерашнего так же является излюбленной темой рефлексии.

И мы увидим в этой тишине,

Как далеко мы были друг от друга.

Как думали, что мчимся на коне,

А сами просто бегали по кругу.

А думали, что мчимся на коне.

(Сплин «Паузы») 
Проблема жизни и смерти. Жизнь и смерть переплетены, никто еще не смог победить смерть и жить вечно в физическом теле. Общепринятый факт, но как его принять, как осознать смерть в качестве закономерного и последнего события жизни.

Нет средства согреться, если вдруг остановилось сердце.

Нет средства от смерти на свете.

Нет средства вернуться, если не получится проснуться.

Нет средства от смерти...

(Би-2 «Из-за меня»)

Рок всегда уделяет проблеме жизни и смерти много внимания. Принятие страха смерти, примирение с ее неизбежностью, понимание смысла не только жизненного пути, но и смерти, необходимость осознания ценности жизни и ее разнообразя.

Пепел легок и светел. Я не заметил, как время прошло.

Чары силу теряют и превращают жемчуг в стекло.

Как пусто в душе без миражей, без волшебства.

Мы здесь лишь на миг.

Пусть он звучит, словно слова молитвы.

Все, кроме любви, вся наша жизнь так далеко.

(Би-2 «Молитва»)

Страх смерти порождает сильную экзистенциальную тревогу.

Осень очень похожа на смерть.

Из спящих деревьев уходит вода.

И я мог бы так же, но слишком боюсь,

Что если уйти, то уйдешь Навсегда!!!

(Lumen «Навсегда»)

Как эту тревогу ослабить, убрать ее негативное влияние. Может через наполнение своей жизни смыслом? В унисон экзистенциализму рок призывает к осмысленному существованию. Необходимо помнить, что жизнь быстротечна, как она часто меняет свой ход, трансформируя наши мысли, наши идеалы и ценности. Мы можем совершенствоваться буквально каждый месяц.

Апрель, научи нас любить. Май, научи нас мечтать.

Январь, научи меня жить. Февраль, научи меня ждать.

(Смысловые галлюцинации «Апрель»)

Экзистенциальный терапевт всегда ставит перед собой вопросы, связанные с чувствами и переживаниями конкретного человека. Что его волнует, что не устраивает, чего хотелось бы в дальнейшем. Работая с запросами клиента, экзистенциальный терапевт старается соединить прошлое и настоящее клиента, наполнить его жизнь будущими смыслами. Это повышает качество жизни и убирает тревогу по поводу смерти. Позволяет человеку четко ставить цели, понимать и видеть пути их реализации. Видеть, что жизнь очень разнообразна и стоит быть прожитой.

Жизнь - это постоянное. Жизнь - это невозможное.

Жизнь - это все понятное. Жизнь - это что-то сложное.

Жизнь - это не собраться с мыслями. Жизнь - это чтото важное.

Жизнь - это очень быстрое. Жизнь - это очень страшное.

(Сплин «Семь восьмых»)

Проблема любви и одиночества. Одиночество - мощная экзистенциальная проблема. Человеческое бытие рефлексивно. Мой Мир - это только мой Мир, пропущенный через призму собственного «Я». Через «Я» пропускается даже то, что напрямую с ним не связано. В этом смысле человек экзистенциально одинок. И открытие этого факта зачастую влечет страхи и разочарования. Не менее жестокую боль человек испытывает от физического одиночества. Формат статьи не позволяет углубиться в эту проблему. Достаточно того факта, что страх одиночества вызывает в человеке деструктивные психо-эмоциональные отклонения.

И совсем не понятно кто я, паранойя в чужом раю.

Там, где я ничего не стою, перед строем один стою.

(Би-2 «Лети»)

Рок может поддержать тебя в трудные минуты, побыть с тобой в унисон, согласиться с невысказанными претензиями.

Зачем кричать, когда никто не слышит,

О чем мы говорим?

Мне кажется, что мы давно не живы -

Зажглись и догорим...

(Lumen «Гореть»)

Рок поможет выплеснуть твою агрессию, выплеснуть просто от прослушивания любимых композиций. Агрессия уходит с музыкой. И не надо что-то крушить, принимать запрещенные препараты. Твои отношения с рок-музыкой - это всегда диалог. Ты вместе с ней высказываешься до конца, до самого своего дна. Твоя экзистенция вибрирует с ней на одной волне.

Вот она гильза от пули навылет,

Карта, которую нечем покрыть.

Мы остаемся одни в этом мире.

Бог устал нас любить.

(Сплин «Бог устал нас любить»)

Чувство одиночества связано с чувством любви. Часто именно в любви человек пытается найти средство от пустоты и тоски одиночества. Он убегает в «другого», но проблема остается. Разочарования в любви усугубляют экзистенциальные страхи, зачастую ставя человека в пограничную ситуацию. 
Не удивляйся, не грусти. Жизнь - это бег у пропасти. Что нам подарит новый шаг?

(Lumen «Привык»)

Рок-музыка мало внимания уделяет так называемой счастливой любви. Скорее она предпочитает проговаривать негативные стороны любви: предательство, ограничение свободы, разрушение иллюзий, невозможность познать другого, неприятие.

Гадай на картах Таро и что осталось от кофе,

Не продырявь мне башку взглядом внимательных глаз.

Твои соленые слезы, кислые мины, душевные речи,

Весь этот бред...

Я умираю от скуки, когда меня кто-то лечит.

(Смысловые галлюцинации «Весь этот бред»)

С другой стороны, любовь часто воспевается как активная сила, способная раскрыть человека, освободить его от правил и норм, научить иррациональным вещам, стать источником творчества.

Все говорят, что любовь - это девятый вал,

Но что же нам делать здесь на берегу.

Я не умею, как те, про кого я читал.

Но пока я люблю, я что-то могу.

Могу хотя бы сказать вам:

Любовь - это все, что мы есть...

(Аквариум «Все, что мы есть»)

Проблема смысла жизни. Фундаментальный вопрос как для человечества в целом, так и для каждого отдельного индивида.

Я иду и пытаюсь найти свое «Я».

Но время наверное сходит с ума.

Знаешь ли ты, куда я иду?

(Би-2 «К оружию»)

Врожденные инстинкты не подсказывают человеку, в отличие от животного, смысл его рождения и существования. Человеку постоянно приходиться сталкиваться с проблемой выбора смысла, цели своего существования. Меня замучила идея:

Куда я мчусь? Кто Я и где Я?

Я встал посередине и «аварийка» замигала,

Мне нужно все начать иначе и сначала!

(Lumen «Гонка»)

Человеческая потребность постоянно находится в познании себя, других, окружающего мира, творит свои смыслы. Утрата смысла происходит от осознания своего одиночества, изолированности и неизбежности смерти.

Ты помнишь, я знал себя. Мои следы лежали как цепи.

Я жил, уверенный в том, что я прав.

Но вот выпал снег, и я опять не знаю Кто?

И кто-то сломан и не хочет быть целым...

(Аквариум «С утра шел снег»)

Смысл жизни человека состоит в наборе ценностей, ради которых он ставит жизненные цели и стремиться их воплотить. Смысл жизни является компонентом духовного смысла существования, составляет индивидуальную человеческую ценностную систему.

Сын человеческий, кто мы? Скажи мне еще один раз.

Скажи мне прямо, кто мы теперь?

Скажи мне истинно, где мы сейчас?

(Аквариум «Комната, лишенная зеркал»)

Процесс открытия смысла жизни глубоко индивидуален. На этом пути много разочарований, побед и падений.

Рок-музыка имеет двойственную природу. С одной стороны, это драйв, сильнейшая энергетика. С другой стороны, это глубокие тексты со смыслом. Они несут в себе множество мировоззренческих аспектов, идей, устанавливают другие нормы и принципы жизни. Заставляют думать, затрагивают глубинные струны души, помогают понять свое предназначение. Рок-музыка является своего рода философией, мировоззрением, отражающим свое время, снимающим с него слепок.

\section{ЛИТЕРАТУРА}

1. Аликин В.А. Свобода и игра в экзистенциализме // Исторические, философские, политические и юридические науки, культурология и искусствоведение. Вопросы теории и практики. 2012. №12-1(26). С.18-22.

2. Буланов В.В. Ценностный выбор и экзистенциализм // Глобальный научный потенциал. 2013. №5(26). С.42-46.

3. Кнабе Г.С. Рок-музыка и рок-среда как формы контркультуры // Кнабе Г.С. Избранные труды. Теория и история культуры. - М.-СПб.: Летний сад; М.: РОССПЭН, 2006.- С. 20-50.

4. Подлиняев 0.Л. Экзистенциальный подход в психологии // Известия Иркутского государственного университета. Серия: Психология. 2012. Т.1. №1. С. $62-68$.

5. Степанович С., Чуева Е. Особенности репрезентации концепта «Свобода» (на материале текстов русских рок-групп) // Вестник Кемеровского Государственного университета. 2008. №2 (34). - С. 193-196.

(c) Фетисова Евгения Николаевна (evseneya@mail.ru). 